\title{
Technological aspects of the creation of intensive plantations of cherries in Forest-Steppe of Ukraine
}

\author{
Kishchak O.. , Grynyk I. ${ }^{2}$, Barabash L. ${ }^{3}$, Kish-chak Yu. ${ }^{4}$ \\ Institute of Horticulture of NAAS \\ 23 Sadova Str., Novosilky village, Kyiv-Sviatoshyn region, Kyiv oblast, 03027, Ukraine \\ e-mail: sad-institut@ukr.net
}

Goal. To make a comparative assessment of the efficiency of cultivation of sweet cherry in modern intensive gardens, using the best domestic and foreign large-fruited varieties, high-yielding stocks, new forms of crowns for the optimally dense layout of trees. Methods. Field, laboratory, comparative and statistical. Results. It was established that trees of variety Reghina in plantings on rootstock Ghizela 5 had a low growth rate, therefore, they had 1.2 times smaller crown volume as compared to medium growth trees on rootstocks Ghizela 6 and VSL-2. Cutting of trees with the spindle-shaped crown in comparison with the rounded compact one needed in 1.3-1.6 times more time. As a result, technological labor input per unit area grew in 1,8-2,2 times. Similar costs needed gardens with large hanging flattened crown. For specific performance the trees of variety Reghina on the rootstocks Ghizela 5 and Ghizela 6 in all the garden designs were in $3.6-6.0$ times less productive than trees of varieties Melitopolska myrna, Talisman, and Annushka. The low productivity of trees $(0.5-0.7 \mathrm{~kg} / \mathrm{m} 3)$ was observed in all plantations with a spindleshaped crown, so the latter is impractical in gardens with the use of classical selection varieties. Conclusions. High-performance design growing spaces were developed for varieties Talisman and Annushka on medium rootstock VSL-2 with a stocking density of 889 trees/ha and the formation of a rounded compact crown, which is $6-7$-years age provide a competitive level of productivity (12.6 tons/ha) and return (120 to 187\%). The average weight of the fruits in these gardens is $8.6-9.6 \mathrm{~g}$ with an average diameter of $27-28 \mathrm{~mm}$. Marketability of products $-79,8-85.6 \%$. In gardens sweet cherry of varieties Reghina on the rootstocks Ghizela 5 and Ghizela 6 secure high level of marketability of production (86 $87,6 \%)$, but due to low performance $(2,3-3,3 \mathrm{t} / \mathrm{ha})$ they are unprofitable and cannot be recommended for forest-steppe of Ukraine.

Key words: design space, shape of the crown, rootstock, yield, fruit weight, marketability. DOI: https://doi.org/10.31073/agrovisnyk202003-04

At the present stage of the horticulture development, the creation of intense orchards is based on the selection of low-sized cultivar rootstock combinations, high-dense schemes of the tree is distribution and appropriate methods of their formation and pruning, the main requirements being to obtain the maximum amount of the high commercial output that could be sold at the highest price [1-3]. Therefore the main requirement to cultivars large-fruitedness according to which the fruit diameter must be not less than 26-28 $\mathrm{mm}[4,5]$.

Among such large-fruited varieties, nursery companies in EU countries advertise and offer actively such cultivars as Regina and Cordia, which, being combined with the small-sized rootstocks of the Gizela series, have become the symbol of the intensive sweet cherry cultivation. Among them Gizela 5 and Gizela 6 have begun to be spread actively in Ukraine since 2010, and in 2011 were entered in the State Register of the Plant Varieties Suitable for Growing in Ukraine [6].

In order to obtain large-sized sweet cherries and prevent their cracking growth stimulants are widely used the orchards of the West European countries [7-9], and the trees pruning highest degree is regulated by their loading with fruits. At the same time, the planned crop volume is provided by the maximum (12004848 trees/ha) trees density per area unit [10]. In these orchards, only dwarf and semi-dwarf rootstocks (Gisela 3, Gisela 5) are used, and spindle-like crowns are formed (Spindle, Tall Spindle Axe (TSA), axelike (Super Slender Axe (SSA) or vertical flattened ones - Drapeau Marchand or Upright Fruiting Offshoots (UFO) [11-14].

The yield of the orchards with such conctructions does not exceed 10-15 t/ha, and the profitability is ensured by the higher exercise price of products $[15,16]$. Because of the short exploitation period (14-15 years), such orchards require significant investments - from 9.5 to 62.5 thousand euros per 1 ha [17].

At the same time, the inland science has considerable developments in the creation of large-fruited sweet cherry cultivars, low vegetative rootstocks, effective ways of sweet cherry the crown formation. Thus, during the latest 30 years, $\quad 500$ new cvs were created throughout the world among them 100 by Ukrainian breeders. Concerning this indicator, Ukraine takes surely the first place in the world and leaves behind significantly USA, Russia, Rumania, Canada, France, Italy and Hungary [18]. The inland breeders have created large-fruited sweet cherry varieties, including Annonce, Krupnoplidna, Talisman, Dilema, Vasylisa Prekrasna, Legenda Mliyeva, Nizhnist' with fruits of high taste qualities and average mass of 10- 
$12 \mathrm{~g}$. Under the irrigation conditions the mass can exceed 14 grams [19]. That's why today it is the inland varieties that predominate in the State Register of the plant Varieties Suitable for Cultivationin Ukraine among the 40 registered ones and only one cultivar (Bigarro Burlat) is foreign. That provides self-sufficiency as for this important technological element and makes it possible to choose the adapted assortment of orchards for different soil and climatic conditions and levels the challenges connected with the climate change and variable demand in the global and domestic markets.

At the Institute of Horticulture of the National Academy of Agrarian Sciences (hereinafter - IH NAAS) of Ukraine, high productive adapted rootstocks were selected and recommended for wide the industrial use: semi-dwarf Studenykivs'ka and average-sized Alpha.

In addition, effective types of sweet cherry orchards on different rootstocks have been developed at IH NAAS which provide stable yield at a level of 10.7-19.2 $\mathrm{t} / \mathrm{ha}$ [20].

In this connection the purpose of our investigations was the comparatively evaluation of the sweet cherry cultivation effectiveness in modern intense orchards using the best inland and foreign large-fruited cvs, high-productive rootstocks, new crown forms with optimally dense tree planting plans. That enabled to select and recommend to production. the best varieties of orchards concerning the productivity and economic effectiency.

Materials and methods. In the spring of 2013 , an experiment was established at IH NAAS on the comparative evaluation of modern sweet cherry intense orchards using perspective inland and foreign cultivar-rootstock combinations. The foreign cv Regina on the rootstocks Gizela 5 and Gizela 6 were investigated as well as the inland varietes Melitopol's'ka Myrna, Talisman and Annushka grafted on VSL-2 as well as were investigated. The orchards on Gisela 5 and Gisela 6 was planted with perennial crowned foreign planting stock and on VSL-2 with standard non-crowned annual planting trees. Three crown were formed - the orbicular small (the planting plan $4 \times 2.5 \mathrm{~m})$, spindle-like and multi-axis flattened $(4-4.5 \times 2.0 \mathrm{~m})$.

The orbicular small crown (hereinafter referred to as the orbicular crown) was formed in accordance with the recommendations of IH NAAS, spindle-like one by means of bending the branches, which were placed uniformly spirally around the leader. On the trees with the multi-axis flattened (hereinafter - flattened) crown on the trunk at a height of 70-100 cm 5-6 branches-axes were selected on which overlying semiboughs were formed that were formed that were not older than 4 years of age. The branches with wide angles of withdrawal from the trunk, which grew vigorously toward the inter-row spacing were kept by means of pruning within the projection of the fruit wall, and with the angles and below $45^{\circ}$ were left and directed vertically.

The thickness of such crown must not exceed $2.5 \mathrm{~m}$. On long the annual branches-axes in spring during the buds swelling was carried out for better shoots branching and formation of bigger amount of fruiting branches.

Each variant includes 9 discount trees, the repetition is three fold one. The soil of the plot was dark gray podzolized light loamy on the carbonate loess it was kept under bare fallow without irrigation.

The estimates and observations concerning the main indicators of growth and fruit-bearing were carried out applying the conventional methods Karpenchuk GK., Mel'nyk A.V. (1987) and Syedova E.M., Ogoltsova T.P. (1999) [21, 22].

Results. The evaluation of the growth processes in different types of the orchards showed that they were less intense on the semi-dwarf rootstock Gisela 5, that appeared in the decrease of the total by as $19.7-36.4 \%$ increment of the number of annual shoots $22.3-26.0 \%$ and of the crown volume by $14.0-25.4 \%$ as compared to the orchards on the middle-sized rootstock Gisela 6.

It should be noted that the five year sweet cherry trees on all the investigated rootstocks achieved the level of the installation of the antihail nets so we had to limit them to a height of $3.5 \mathrm{~m}$ and on the sides of the inter rows spacing. Despite this, the volume of the tree crown varied depending on the rootstock growth vigour. For instance, on the semi-dwarf rootstock Gisela 5 by it was 6.7-7.0 $\mathrm{m}^{3}$ the end of the seventh vegetation, and on the middle-sized ones (VSL-2 and Gisela 6), especially in the version with the orbicular small crown, where the trees grew more intensively towards the row and row spacing - 7.3- $\quad 8.9 \mathrm{~m}^{3}$ (fig. 1). 


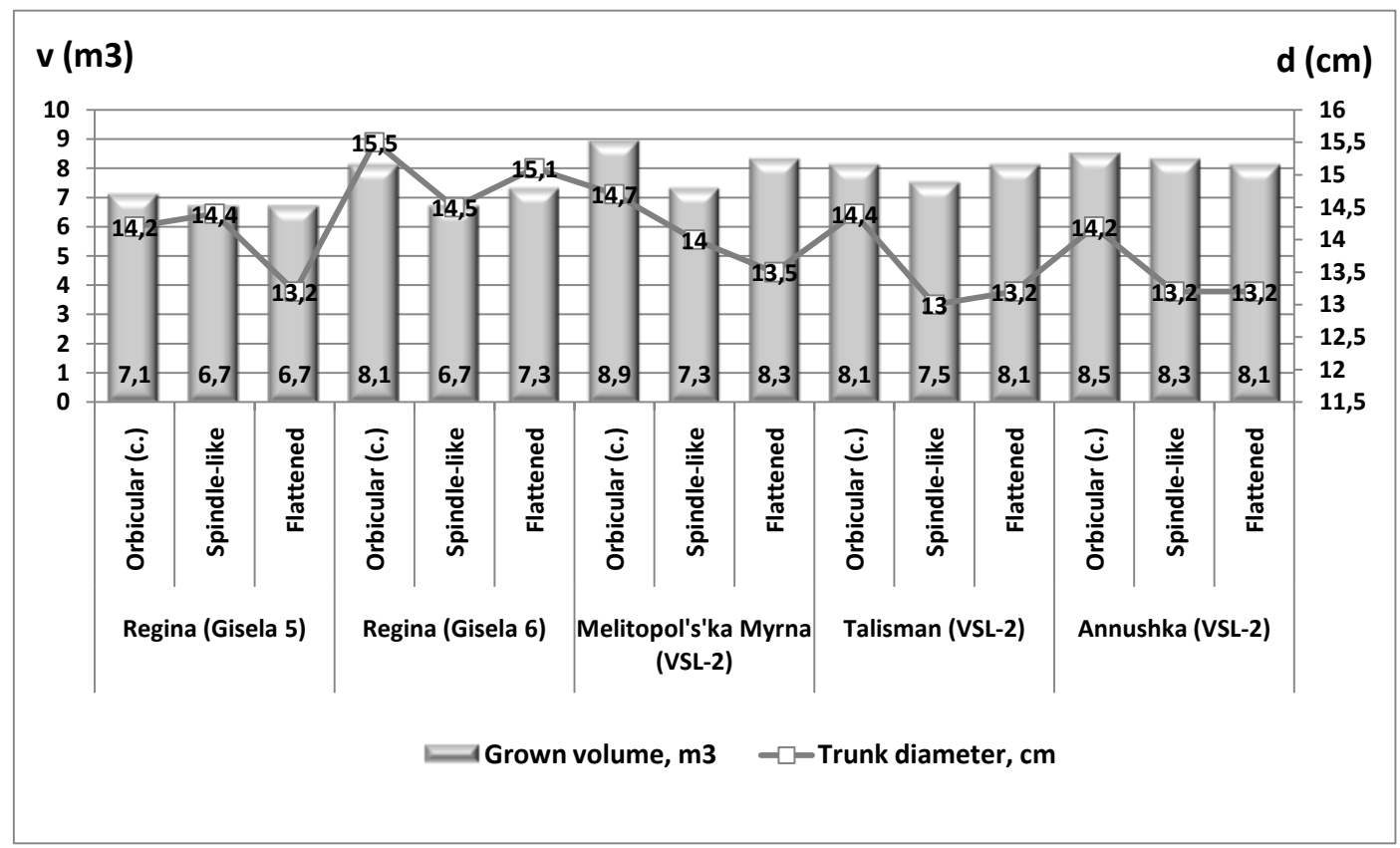

Fig. 1. Crown volume and trunk diameter of 7 year old sweet cherry trees in different orchard consructions. Planting in 2013

At the same time, in keeping with the trunk diameter no significant difference between the treatments was observed and in the sixth year after planting it was $13.0-15.5 \mathrm{~cm}$ on both the semi-dwarf rootstock Gisella 5 and the middle one VSL-2 and Gisella 6 with its larger values the trees with the orbicular small crown. Beginning in 2018, the crown parameters were limited so that the light passage remained at a level of $2 \mathrm{~m}$.

When choosing the crown form for an intense orchard the following requirements should be taken into account: easiness of formation, ability to ensure the balance of vegetative and generative processes and achieve early and regular fruit-bearing. Studying the technological and exploitation peculiarities of different crown formation systems showed that less time expenditures were observed while creating the orbicular small crown, whereas the spindle-like one formation was by 2.0-3.7 times more cost-based. This was connected with the additional unbending and tying up branches and their cyclical replacement. The same concerned to the multi-axis flattened crown, when nicking shoots and branches was foreseen to improve branching. As a result the in technological labour costs increased by $12-18 \%$ when carrying out these operations. In the fruit-bearing age pruning trees with the spindle-like crown also remains the most expensive.

For instance, on the average for 2018-2019, the technological labour costs on pruning in these variants ranged from 55.7 man-hours / ha (the cultivar Talisman) to 90.5 man-hours/ha (Regina) that is by 1.8-2.2 times more than when pruning the trees with the orbicular small crown (Fig. 2). This is accounted by the fact that when pruning spindle-like crowns, a considerable part of time was spent on the cyclical substitution of the semi-skeletal branches and the strong thinning of the upper part of the crown, where a considerable amount of increments was formed by means of the last year's pruning.

Among the studied varieties just Regina was the one with the high shoot-forming capacity, especially when forming the spindle-like crown, due to which the labour costs on pruning was higher. 


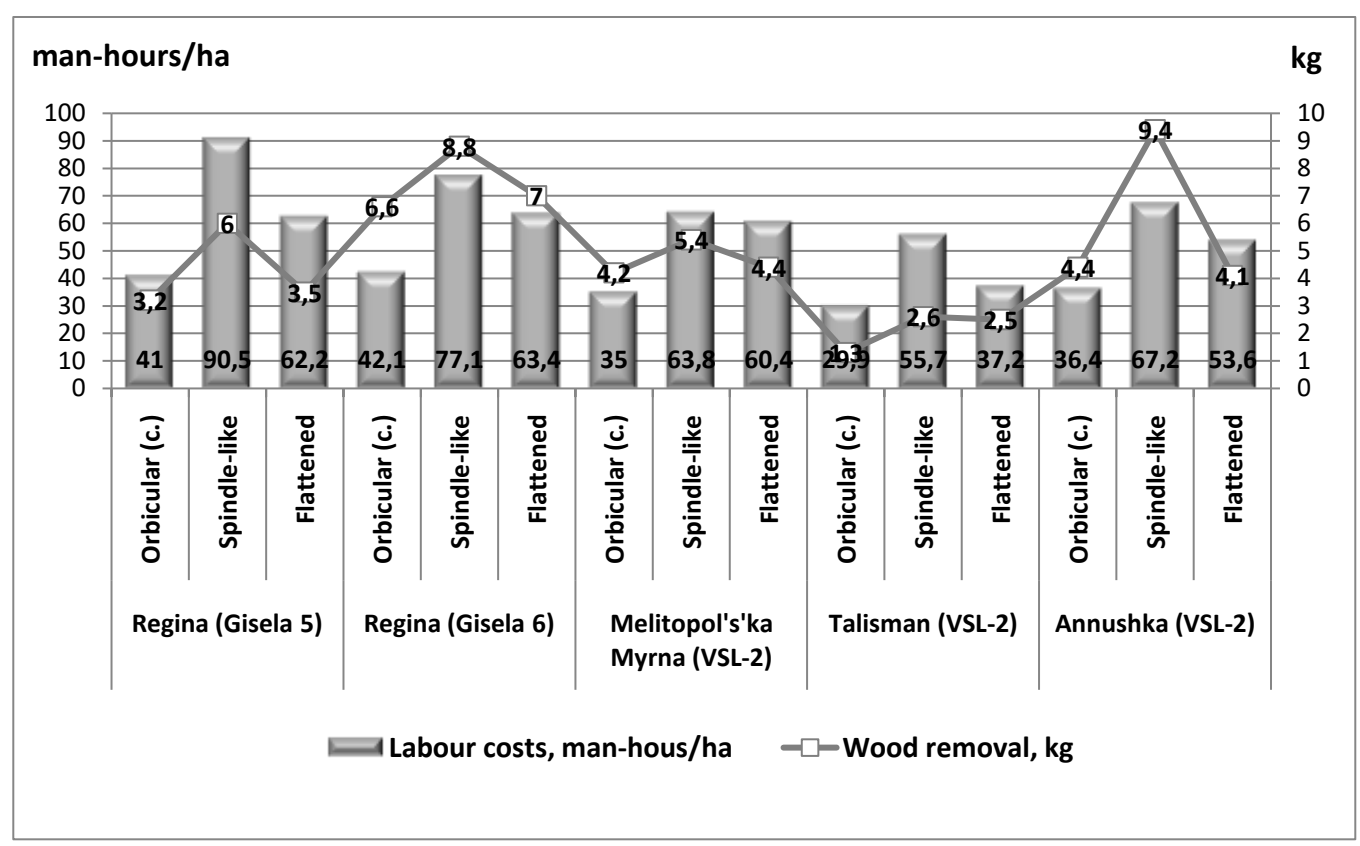

Fig. 2. Labour costs and amount of wood removed when pruning trees in orchards of different constructions. Average for 2018-2019

The crowns of this $\mathrm{cv}$ trees thickened essentially and needed careful thinning. Therefore, even on the semi-dwarf rootstock Gisela 5, the amount of time spent per 1 tree of this variety was 151-237 sec depending on the formation method. That is by 1.2-1.4 times more than concerning in the trees of the other studied cultivars even the more vigorous rootstock VSL-2. It should be noted that the high degree of the sweet cherry trees pruning does not always contribute to better branching. Newly formed shoots become very long (up to 1.0-1.5 m) and often have a vertical position, and that's why require again strong shortening. Therefore, the mass of the branches removed when trimming the spindle-like crown was 6.0-9.4 kg depending on the variety, that is by 1.3-2.1 times more than in the control.

It is more difficult to form the spindle-like crown trees of the classical selection cultivar such as Talisman, Melitopol's'ka Myrna because of their low shoot-forming capacity and a distinct establishment of boughs as compared to the new-generation cvs (Regina, Annushka). That's whu it is inexpedient to grow those varieties in high-density orchards with the spindle-like crown formation, as they will be bare and lowproductive.

Pruning the multi-axis flattened crown in all the variants of the experiment took 1.2-1.5 times less time than on the spindle-like one. That connected with the reduced intensity of the tree growth and necessity of their essential thinning. It should also be noted that the technological labour costs for pruning trees increased by $12-15 \%$ due to the trees compaction from 889 to $1250 \mathrm{der} / \mathrm{ha}$.

Among the stone crops the sweet cherry is characterized by the latest beginning of the trees fruitbearing, so when creating intense orchards it is necessary to select precocious cultivars which when growing on low rootstocks combining with effective methods of the formation provide fruit-bearing in the $3 d-4$ th years after planting. This makes it possible to reduce the unproductive orchard period by 1-2 years and creates real prerequisites for the rapid productivity increase.

In our experiments the first flowering of the trees of cv Regina on Gizela 5 and Gizela 6 and in the orchard of Annushka on VSL-2 with the formation of the spindle-like crown was noted in the third year after planting. In such orchards the degree of flowering (the 9 point scale) was $8.0-8.5$ points. However, because of the early spring frosts on April 21-22 (minus $0.8-1.0^{\circ} \mathrm{C}$ ) the infructescense was low and the number of the fruits which formed was 2-5 pcs tree.

In the next years of the researches (2016-2019), despite the excessive trees flowering in the orchards of the variety Regina, the degree of the fruit infructescense was law regardless the crown form and averaged $4.2-8.8 \%$ in $2016-2019$. That affected negatively the crop yield.

For example, the highest harvest of the cultivar Regina per tree was noted in the orchards on Gizela 5 and Gizela 6 with the formation of the orbicular small crown, where the yield averaged at $2.6-2.7 \mathrm{~kg} / \mathrm{tree}$ in the latest 4 years and when forming the spindle-like one the yield was only $1.8-2.1 \mathrm{~kg} /$ tree.

Nicking annual branches in the treatments with the multi-axis crown effected positively the increase of the number of lateral branchings with fruit buds by 1.3-1.4 times. That in turn, enabled to achieve higher level of yield in the first years of fruit-bearing as to the ocrhards compared with the spindle-like crown.

It is the specific crop load per $1 \mathrm{~m}^{3}$ of the that crown volume importance when evaluating the orchards productivity. According to this indicator, the trees of cv Regina on the rootstocks Gisella 5 and Gisella 6 at the age of seven years regardless were low-productive $\left(0.3-0.5 \mathrm{~kg} / \mathrm{m}^{3}\right)$ and inferior to $3.6-6.0$ times the trees of Melitopol's'ka Myrna, Talisman and Annushka, grafted on VSL-2 and formed with the orbicular 
small crown $\left(1.8 \mathrm{~kg} / \mathrm{m}^{3}\right)$ irrespective of the method of the crown formation. Besides the low productivity of these cultivar-rootstock combinations $\left(0.5-0.7 \mathrm{~kg} / \mathrm{m}^{3}\right)$ was noted in all the variants with the spindle -like crown, which makes it unpromising for the use in intense orchards.

The high degree of the loading with the fruits of the trees of the inland cvs formed with the orbicular small crown made it possible to provide the yield on the rootstock VSL-2 within 12.8-14.1 t/ha, that is by 3.4-4.0 times more than of, Regina on the rootstocks Gisela 5 and Gisela 6. On the average in the years 2018-2019 it was 11.1-12.6 t/ha (table 1).

1. Yield and commercial quality of products depending on the orchard construction

\begin{tabular}{|c|c|c|c|c|c|c|}
\hline \multirow[b]{2}{*}{$\begin{array}{l}\text { Crown } \\
\text { form }\end{array}$} & \multirow[b]{2}{*}{$\begin{array}{l}\text { Plantin } \\
\text { g plan, } m\end{array}$} & \multicolumn{3}{|c|}{ Yield, t/ha } & \multirow{2}{*}{$\begin{array}{c}\text { Average } \\
\text { fruit mass } \\
\text { in } 2016- \\
2019, \mathrm{~g} \\
\end{array}$} & \multirow{2}{*}{$\begin{array}{c}\text { Fruits } \\
\text { marketability } \\
\text {, in 2016- } \\
2019 \%\end{array}$} \\
\hline & & *2018 & 2019 & $\begin{array}{l}\text { Averag } \\
\mathrm{e}\end{array}$ & & \\
\hline \multicolumn{7}{|c|}{ Regina on Gisela 5} \\
\hline (c) Orbicular & $\begin{array}{l}4.5 x \\
2.5\end{array}$ & $\begin{array}{l}2.2 \pm \\
0.15\end{array}$ & $\begin{array}{l}3.4 \pm \\
0.75\end{array}$ & 2.8 & $\begin{array}{l}8.8 \pm 0.5 \\
7\end{array}$ & 85.9 \\
\hline like & $\begin{array}{l}4.0 x \\
2.0\end{array}$ & $\begin{array}{l}1.7 \pm \\
0.25\end{array}$ & $\begin{array}{c}2.9 \pm \\
0.59\end{array}$ & 2.3 & $\begin{array}{c}8.8 \pm 0.7 \\
2\end{array}$ & 86.8 \\
\hline d Flattene & $\begin{array}{l}4.0 x \\
2.0\end{array}$ & $\begin{array}{c}2.2 \pm \\
0.12\end{array}$ & $\begin{array}{l}3.9 \pm \\
0.28\end{array}$ & 3.0 & $\begin{array}{c}9.3 \pm 0.5 \\
1\end{array}$ & 86.4 \\
\hline \multicolumn{7}{|c|}{ Regina on Gisela 6} \\
\hline (c) Orbicular & $\begin{array}{l}4.5 x \\
2.5\end{array}$ & $\begin{array}{c}2.2 \pm \\
0.59\end{array}$ & $\begin{array}{l}3.7 \pm \\
0.52\end{array}$ & 2.9 & $\begin{array}{l}9.6 \pm 0.5 \\
5\end{array}$ & 87.6 \\
\hline like & $\begin{array}{l}4.0 x \\
2.0\end{array}$ & $\begin{array}{l}1.9 \pm \\
0.39\end{array}$ & $\begin{array}{l}4.5 \pm \\
1.19\end{array}$ & 3.2 & $\begin{array}{l}9.5 \pm 0.9 \\
2\end{array}$ & 87.5 \\
\hline d Flattene & $\begin{array}{l}4.0 x \\
2.0\end{array}$ & $\begin{array}{l}1.7 \pm \\
0.29\end{array}$ & $\begin{array}{c}4.9 \pm \\
0.47\end{array}$ & 3.3 & $\begin{array}{l}9.6 \pm 0.6 \\
7\end{array}$ & 87.5 \\
\hline \multicolumn{7}{|c|}{ Melitopol's'ka Myrna on VSL-2 } \\
\hline (c) Orbicular & $\begin{array}{l}4.5 x \\
2.5\end{array}$ & $\begin{array}{c}8.2 \pm \\
0.25\end{array}$ & $6^{14.1 \pm 0.2}$ & 11.1 & $\begin{array}{l}8.1 \pm 0.3 \\
6\end{array}$ & 80.5 \\
\hline like & $\begin{array}{l}4.5 x \\
2.0\end{array}$ & $\begin{array}{c}4.0 \pm \\
0.20\end{array}$ & $\begin{array}{c}6.0 \pm \\
1.28\end{array}$ & 5.0 & $\begin{array}{l}8.3 \pm 0.3 \\
5\end{array}$ & 81.5 \\
\hline $\begin{array}{l}\text { Flattene } \\
\text { d }\end{array}$ & $\begin{array}{l}4.5 x \\
2.0\end{array}$ & $\begin{array}{l}8.1 \pm \\
1.56\end{array}$ & $\begin{array}{l}6.7 \pm \\
0.79\end{array}$ & 7.4 & $\begin{array}{c}8.2 \pm 0.2 \\
0\end{array}$ & 81.5 \\
\hline \multicolumn{7}{|c|}{ Talisman on VSL-2 } \\
\hline (c) Orbicular & $\begin{array}{l}4.5 x \\
2.5\end{array}$ & $\begin{array}{c}12.5 \pm 0.2 \\
5\end{array}$ & $\begin{array}{c}12.8 \pm 0.4 \\
3\end{array}$ & 12.6 & $\begin{array}{l}8.6 \pm 0.9 \\
0\end{array}$ & 85.6 \\
\hline like & $\begin{array}{l}4.5 x \\
2.0\end{array}$ & $\begin{array}{c}4.1 \pm \\
0.07\end{array}$ & $\begin{array}{l}3.8 \pm \\
0.80\end{array}$ & 3.9 & $\begin{array}{c}9.0 \pm 0.7 \\
0\end{array}$ & 86.5 \\
\hline Flattened & $\begin{array}{l}4.5 x \\
2.0\end{array}$ & $\begin{array}{c}8.1 \pm \\
1.92\end{array}$ & $\begin{array}{c}6.5 \pm \\
0.39\end{array}$ & 7.3 & $\begin{array}{c}8.6 \pm 0.7 \\
1\end{array}$ & 86.2 \\
\hline \multicolumn{7}{|c|}{ Annushka on VSL-2 } \\
\hline (c) Orbicular & $\begin{array}{l}4.5 x \\
2.5\end{array}$ & $\begin{array}{c}11.5 \pm 1,8 \\
9\end{array}$ & $\begin{array}{c}13.8 \pm 2.1 \\
6\end{array}$ & 12.6 & $\begin{array}{l}9.1 \pm 0.3 \\
6\end{array}$ & 79.8 \\
\hline like & $\begin{array}{l}4.5 x \\
2.0\end{array}$ & $\begin{array}{c}6.6 \pm \\
1,55\end{array}$ & $\begin{array}{l}4.4 \pm \\
0.43\end{array}$ & 5.5 & $\begin{array}{l}9.1 \pm 0.4 \\
8\end{array}$ & 77.0 \\
\hline d Flattene & $\begin{array}{l}4.5 x \\
2.0\end{array}$ & $\begin{array}{c}12.2 \pm 3,3 \\
1\end{array}$ & $\begin{array}{c}9.9 \pm \\
1.83\end{array}$ & 11.0 & $\begin{array}{c}9.6 \pm 0.2 \\
2\end{array}$ & 78.6 \\
\hline
\end{tabular}

* In 2017 the marketable crop was absent due to the ovary severe damage by the May frost.

The level of the fruits marketability depended to the important degree on the weather conditions that occurred when they ripened.

Thus, because of the high au humidity and excessive rainfall. In the May of 2016 (103.6 mm), that is by twice the average two-year norm, to the greatest extent the fruits of the medium term maturity varieties were damaged namely $(103.6 \mathrm{~mm}$ ): Melitopol's'ka Myrna (the fruit cracking was 12.6-14.0\%) and Talisman (16.0-16.9\%). In additions the marketability decrease was influenced by the damage by birds (3.3-5.1\%), owing to the number of the intact fruits was only $67.4-69.8 \%$.

It was the late cultivar Regina fruits that had the market able indices. Their damage by birds was practically absent, because at this time the mulberry fruits were more attractive for them. Taking into consideration that these fruits ripened in a hot weather, their cracking was minimum (0.8-3\%). All this ensured the high level of their marketability - 92.6-94.3\%. 
Favourable conditions for the sweet cherry fruits high marketable quality turned out in 2018. Sufficient supplies of the productive moisture in soil, which had appeared as a result of heavy rainfalls in March and the lack of them during the fruits ripening, provided high marketability of inland cvs at a level of 87.3-96.2\%.

The rainfalls on June 13 and $14(4.76 \mathrm{~mm}$ each) during the harvesting period did not cause the fruits cracking even of the varieties inclined to it.

The biggest precipitations amount in June $(22.92 \mathrm{~mm})$ was noted on 19.06, when practically the whole crop of the main cultivars had been harvested and only the fruits of the latest cv Regina remained on the tree. After fall of such precipitations number the amount of cracked fruits was $10.3 \%$, Annushka 18.1, and of Regina highest, including on the rootstock Gisela 6 16.9-18.7, and on Gisela $59.3-21.1 \%$. During the period of this variety full maturation after the precipitation on July $1(8.96 \mathrm{~mm})$ and $2(3.64 \mathrm{~mm})$ the number of the cracked fruits it increased to $22.4 \%$. As a result, the marketability of the Regina fruits was only $76.5-$ $81.1 \%$, and of Talisman and Annushka 94.1-95.7\%.

The decrease of the middle cultivar Melitopol's'ka Myrna fruits marketability was influenced by the bigger damage by birds (2.1-4.4\%), and as a consequence, rot (3.2-5.5\%). In this connection the intact fruits amount was $87.3-90.8 \%$.

In 2019 thanks to the uniform soil supply with moisture during May the fruits cracking in all the types of the orchard was minimum $-0-1,1 \%$, but their affection with fungal diseases ranged from 2.1 to $7.2 \%$, especially of the fruits of Melitopol's'ka Myrna. Therefore the number of undamaged fruits was only 84.2$84.7 \%$, while in other variants $88.2-94.2 \%$.

On the average, in the research years of (2016-2019), garden provided the sufficiently high products marketability level with the highest values of the cultivar-rootstock combinations Talisman on VSL-2 (85.6$86.5 \%)$ and Regina on Gisela $6(87.5-87.6 \%)$ was ensured in all the types of the orchard.

During the investigation years the average fruit mass did not depend on the methods of formation and was 8.8-9.3 g (Regina on Gisela 5 with the somewhat higher index on Gisela 6 9.5-9.6 g., the average fruit diameter being 25.6-26.3 mm. The same referred Talisman and Annusha fruits - 8.6-9.6 g (diameter was 27.0-28.3 mm), while the corresponding indices of Melitopol's'ka Myrna were 8.1-8.3 g and 24.3-25.0 mm respectily. It was the cvs Talisman and Annushka that had the largest individual fruits (the largest fruit mass was $18.4 \mathrm{~g}$ and $12.1 \mathrm{~g}$ respectively and diameter $35 \mathrm{~mm}$ and $31 \mathrm{~mm}$ respectively) while the corresponding indicators of the Regina fruits were $12 \mathrm{~g}$ and $30 \mathrm{~mm}$ respectivyely.

So it was the Talisman and Anushka orchards on the middle rootstock VSL-2 (889 trees/ha) and the orbicular small crown that had the highest indices in the seven years age - the competitive levels of yield $12.8-14,1 \mathrm{t} / \mathrm{ha}$ ) and fruits marketability (89.7-94.2\%). This type of the orchard provides the yield of the high quality products that meet the global trade networks requirements.

The comparative economic evaluation of different orchards constructions showed that it was hose those with the high density of trees planting (1111-1250 trees/ha) and spindle-like and multi-axis flattened crowns were characterized with the highest capital output ratio of creation and with the lowest the orchards with a density of 889 trees/ha and the orbicular, small crowns, where the expenditures on their creation were 428.6-492.1 thousand grn. (411.6 thousand grn./ha).

The highest indicators of the economic efficiency were noted in the orchards of the inland varieties Melitopol's'ka Myrna, Talisman and Annushka on the rootstock VSL-2 with the orbicular small and multiaxis flattened crowns, where the profit hectare on the average in 2018-2019 was 91.4-215.0 thousand grn./ ha, and the level of profitability $71.6-129.5 \%$ (table 2). The rate of return cost recovery thanks to the accelerated rates of the crop increase occurred when using the orbicular small crown and was 4.9-5.2 years. In the orchards with the spindle-like crown and utililization of these cultivar-rootstock combinations due to the low trees productivity, the profit was by 4.2-11.7 times lower, and the rate of return cost recovery investmens will be only from the 12 the year. It should be noted that in the orchards on medium-sized rootstocks, the productive use period, was only 15-17 years depending on cv.

\section{Comparative economic evaluation of different types of sweet cherry} orchards. Planting in 2013

\begin{tabular}{|c|c|c|c|}
\hline \multirow{2}{*}{ Indication } & \multicolumn{3}{c|}{ Crown form } \\
\cline { 2 - 4 } & orbicular & $\begin{array}{c}\text { spindle- } \\
\text { like }\end{array}$ & flattened \\
\hline \multicolumn{1}{|c|}{ Regina on PeziHa Gisela 5 } & 2.8 & 2.3 & 3.1 \\
\hline Yield, c/ha, average in 2018-2019 & 85.3 & 88.6 & 94.9 \\
\hline Production expenditures per 1 ha, thousand grn. & 90.9 & 93.2 & 101.1 \\
\hline $\begin{array}{c}\text { Production costs of the realized products, thousand } \\
\text { grn. }\end{array}$ & 32.5 & 40.5 & 32.6 \\
\hline Full production costs of 1 t of fruits, thousand grn. & 84.0 & 69.0 & 93.0 \\
\hline $\begin{array}{c}\text { Cost of products per 1 ha in the realization prices } \\
\text { thousand grn. }\end{array}$ & -6.9 & -24.2 & -8.1 \\
\hline Profit per 1 ha, thousand grn. & -7.6 & -26.0 & -8.0 \\
\hline Profitableness level, \% & & & \\
\hline
\end{tabular}




\begin{tabular}{|c|c|c|c|}
\hline $\begin{array}{l}\text { Investments on the establishment of } 1 \text { ha offorchards, } \\
\text { thousand grn. }\end{array}$ & 449.3 & 492.1 & 492.1 \\
\hline $\begin{array}{l}\text { Term of the rate of return cost recovery of } \\
\text { investments, years }\end{array}$ & & & \\
\hline \multicolumn{4}{|c|}{ Regina on Регіна Gisela 6} \\
\hline Yield, c/ha, average in 2018-2019 & 3.0 & 3.2 & 3.3 \\
\hline Production expenditures per 1 ha, thousand grn. & 87.6 & 95.1 & 96.0 \\
\hline $\begin{array}{l}\text { Production costs of the realized products, thousand } \\
\text { grn. }\end{array}$ & 93.6 & 101.5 & 102.6 \\
\hline Full production costs of $1 \mathrm{t}$ of fruits, thousand grn. & 31.2 & 31.7 & 31.1 \\
\hline $\begin{array}{l}\text { Cost of products per } 1 \text { ha in the realization prices } \\
\text { thousand grn. }\end{array}$ & 90.0 & 96.0 & 99.0 \\
\hline Profit per 1 ha, thousand grn. & -3.6 & -5.5 & -3.6 \\
\hline Profitableness level, \% & -3.8 & -5.4 & -3.5 \\
\hline $\begin{array}{l}\text { Investments on the establishment of } 1 \text { ha offorchards, } \\
\text { thousand grn. }\end{array}$ & 449.3 & 492.1 & 492.1 \\
\hline $\begin{array}{l}\text { Term of the rate of return cost recovery of } \\
\text { investments, years }\end{array}$ & & & \\
\hline \multicolumn{4}{|l|}{$\begin{array}{ll} & \text { Talisman on VSL-2 } \\
\end{array}$} \\
\hline Yield, c/ha, average in 2018-2019 & 12.7 & 4.0 & 7.3 \\
\hline Production expenditures per 1 ha, thousand grn. & 140.6 & 93.6 & 113.0 \\
\hline $\begin{array}{l}\text { Production costs of the realized products, thousand } \\
\text { grn. }\end{array}$ & 16.0 & 101.6 & 127.6 \\
\hline Full production costs of $1 \mathrm{t}$ of fruits, thousand grn. & 13.1 & 25.4 & 17.5 \\
\hline $\begin{array}{l}\text { Cost of products per } 1 \text { ha in the realization prices } \\
\text { thousand grn. }\end{array}$ & 381.0 & 120.0 & 21.0 \\
\hline Profit per 1 ha, thousand grn. & 215.0 & 18.4 & 91.4 \\
\hline Profitableness level, \% & 129.5 & 18.1 & 71.6 \\
\hline $\begin{array}{l}\text { Investments on the establishment of } 1 \text { ha offorchards, } \\
\text { thousand grn. }\end{array}$ & 411.6 & 428.6 & 428.6 \\
\hline $\begin{array}{l}\text { Term of the rate of return cost recovery of } \\
\text { investments, years }\end{array}$ & 4.9 & 26,3 & 7.7 \\
\hline \multicolumn{4}{|l|}{ Annushka on VSL-2 } \\
\hline Yield, c/ha, average in 2018-2019 & 12.7 & 5.5 & 11.1 \\
\hline Production expenditures per 1 ha, thousand grn. & 140.6 & 102.7 & 134.8 \\
\hline $\begin{array}{l}\text { Production costs of the realized products, thousand } \\
\text { grn. }\end{array}$ & 166.0 & 113.7 & 157.0 \\
\hline Full production costs of $1 \mathrm{t}$ of fruits, thousand grn. & 13.1 & 20.7 & 14.1 \\
\hline $\begin{array}{l}\text { Cost of products per } 1 \text { ha in the realization prices } \\
\text { thousand grn. }\end{array}$ & 381.0 & 165.0 & 333.0 \\
\hline Profit per 1 ha, thousand grn. & 215.0 & 51.3 & 176.0 \\
\hline Profitableness level, $\%$ & 129.5 & 45.1 & 112.1 \\
\hline $\begin{array}{l}\text { Investments on the establishment of } 1 \text { ha offorchards, } \\
\text { thousand grn. }\end{array}$ & 411.6 & 428.6 & 428.6 \\
\hline $\begin{array}{l}\text { Term of the rate of return cost recovery of } \\
\text { investments, years }\end{array}$ & 4.9 & 11.4 & 5.4 \\
\hline
\end{tabular}

At the same time, the growing of the variety Regina on the rootstocks Gisela 5 and Gisela 6 proved to be loss-making (minus 3.6-24.2 thousand/ha) at 6-7 years of age under all the methods of the trees formation and pruning, so these orchards can not be recommended for the industrial cultivation.

In the process of the researches the trees of the sweet cherry varieties of the classical breeding are not suitable for creating high-density orchards with the spindle-like crown. The confirmation of this is the experience of the world's greatest producer of the sweet cherry fruit in Turkey, where such type cultivar 0900 Ziraat is grown almost on $85 \%$ of the area. It is the basis of the industrial assortment but concerning their biological peculiarities does not meet the requirements of the intensive horticulture. This $\mathrm{cv}$ is grafted on the vigorous seedling rootstocks mahaleb cherry and wild sweet cherry, and Regina the on Gisela 5 only $5 \%$ of the orchards in this country [23]. Besides, according to the American scientists data Regina does not provide high productivity as compared to cvs Bing and Sweetheart [24]. In keeping with the Czech scholars information [25], the total crop of the variety Regina on 10 studied rootstocks, among them those of the series Gisela during the research years was by $40-60 \%$ lower than Lapins had. 
Taking into consideration that the global trade networks have increased significantly the requirements to the sweet cherry fruits marketable quality in its countries-producers the tendency has arisen to reduce the dwarf and semi-dwarf rootstocks application because they do not provide high products marketability during the orchards productive use. Therefore orchards on middle-sized and vigorous rootstocks are introduced actively on which trees are formed with orbicular crowns, in particular, of KGB type, Spanish Bush, orbicular small one and others. At the same time the use of the leading crowns (TSA, SSA) in dense, orchards ensures early ripening and large fruits obtaining the drawback is high labour expenditures and trees alternate fruit-bearing.

Our explorations have proved the effectiveness of growing new types of sweet cherry orchards in the Lisosteppe of Ukraine. The comparative estimation of the cultivar-rootstock combinations productivity, methods of the crown formation, labour expenditures when trees pruning has showed the greater perspectiveness of the adapted inland cvs Talisman and Annushka grafted on the middle-sized rootstock VSL-2 as compared to the German variety Regina on Gisela 5. Our data on the less vigorousness of the trees on Gisela 5 than on VSL-2, Colt, and Gisela 6 correlate with the results of the researches of the scientists of different countries [26, 27]. In this connection that rootstock is recommended for high-dense orchards and controlled conditions. At the same time, the on VSL-2 and Gisela 6 are better adapted to the environmental conditions. This makes it possible to obtain stable sweet cherry crops.

\section{Conclusions}

The comparison of the best inland sweet cherry varieties with popular cultivars of the foreign breeding has shown that they are competitive and not inferior to them as for yield and fruits marketable quality.

The trees of Talisman, Melitopol's'ka Myrna (the classical breeding), as compared with cvs of the new generation (Regina, Anushka) are characterized with low shoot-formation capacity and decent story establishment of boughs and it is not expedient to form them in spindle-like crowns.

The results of the comparative evaluation of the orchards created in the Ukraine's Lisosteppe under the by foreign and inland technologies show that the use of Ukrainian varieties in orchards including Talisman and Anushka on the middle-sized rootstock VSL-2 with the formation of the orbicular small crown under the planting density 889 trees/ha ensures the decrease of the volume of investments on the their creation by 1.2 times, the high level of productivity (12.6 t/ha) and products marketability (79.8-85.6\%) and are favourable for economy.

The constructions of the cultivars Regina orchards on Gizela 5 and Gizela 6 with the spindle-like crown and planting density of 1250 trees/ha because of the high capital investments expenditures and low yield (2.3-3.3 t/ha) appeared ineffective with which recommended for creation in the mentioned area.

\section{References}

1. Kappel, F., Grander, A., Hrotko, K., \& Schuster, M. (2012). Cherry. Handbook of Plant Breeding, 8, 459-504. doi: 10.1007/978-1-4419-0763-9-13.

2. Balmer, M. (2015). Excursion report: sweet cherry growing in Australia. Erwerbs-Obstbau, 57(3), 107-111. doi: 10.1007/s10341-015-0237-7.

3. Bujdoso, G., \& Hrotko, K. (2016). Performance of three Hungarian early sweet cherry cultivars on some novel bred rootstocks. Acta Horticulturae, 1139, 153-158. doi: 10.17660/ActaHortic.2016.1139.27.

4. Blanco, V., Zoffoli, J. P., \& Ayala, M. (2019). High tunnel cultivation of sweet cherry (Prunus avium L.): physiological and production variables. Scientia Horticulturae, 251, 108-117. doi: 10.1016/j.scienta. 02.023 .

5. Meland, M., Froynes, O., \& Kaiser, C. (2017). High tunnel production systems improve yields and fruit size of sweet cherry. Acta Horticulturae, 1161, 117-124. doi: 10.17660/ActaHortic.2017.1161.20.

6. Derzhavnyi Reiestr sortiv roslyn, prydatnykh dlia poshyrennia v Ukraini na 2019 rik. (2019) [State Register of the Plant Cultivars Favourable For the Spread in Ukraine for 2019]. Available at https://sops.gov.ua/reestr-sortiv-roslin. [In Ukrainian].

7. Bound, S. A., Close, D. C., Measham, P. F., \& Whiting, M. D. (2017). Regulating crop load of 'Sweetheart' and 'Van' sweet cherry for optimal quality and reduced risk of cracking. Acta Horticulturae, 1161, 91-95. doi: 10.17660/ ActaHortic. 2017.1161.16.

8. Li, M., Cheng, SC., Wang, Y., \& Dong Yu. (2019). Improving Fruit Coloration, Quality Attributes, and Phenolics Content in 'Rainier' and 'Bing' Cherries by Gibberellic Acid Combined with Homobrassinolide. Journal of plant growth regulation. doi: 10. 1007/s00344-019-10049-4.

9. Zhang, C. X., \& Whiting, M. (2012). Plant growth regulators improve sweet cherry fruit quality without reducing endocarp growth. Scientia hortuculturae, 150, 73-79. doi: 10.1016/j.scienta.2012.10.007.

10. Grandi, M., \& Lugli, S. (2017). Effects of rootstock and training system on fruit quality of new sweet cherry cultivars. Acta Horticulturae, 1161, 133-135. doi: 10.17660/Acta Hortic.2017.1161.22. 
11. Szpadzik, E., Krupa, T., Niemiec, W., \& Jadczuk-Tobjasz, E. (2019). Yielding and fruit quality of elected sweet cherry (Prunus avium) cultivars in the conditions of Central Poland. Acta Scientiarum, 18(3), 117-126. doi: 10.24326/asphc 2019.3.11.

12. Neilsen, D., Neilsen, G. H., Forge, T., \& Lang, G. A. (2016). Dwarfing rootstocks and training systems affect initial growth, cropping and nutrition in 'Skeena' sweet cherry. Acta Horticulturae, 1130, 199205. doi: 10.17660/ActaHortic 1130.29.

13. Soysal, D., Demirsoy, L., Magit, I., Lang, G., \& Demirsoy, H. (2019). Applicability of new training systems for sweet cherry in Turkey. Turkish journal of agriculture and forestry, 43(3), 318-325. doi: 10.3906/tar-1808-104.

14. Long, L., Long, G., Musacchi, S., \& Whiting, M. (2015). Cherry training systems. A Pacific Northwest Extension Publication. Oregon State University.

15. Musacchi, S., Gagliardi, F., \& Serra, S. (2015). New Training Systems for High-density Planting of Sweet Cherry. Horticultural Science, 50(1), 59-67. doi: 10.21273/Hortsci.50.1.59.

16. Makosh, E. (1999). Intensyfikatsiia kultury chereshni v Zachidnii levropi [Intensification of the sweet cherry cultivation in Western Europe]. Horticultural News, 3, 16-19. [In Ukrainian].

17. Mielnik, S. (2017). Intensivnoie vyrashchivaniie chierieshni: siekriety francuzskich konsultantov [Sweet cherry intensive cultivation: secrets of the French consultants]. Gardening and viticulture. Technologies and innovation, 5(7), 74-76. [In Russian].

18. Milatović, D., \& Nikolić. (2011). Oplemenjivanje trešnje i višnie u svetu. Zbornik radova universitet u Beogradu. Inovacije u voćarstru. Beograd.

19. Kishchak, O. A., \& Kishchak, Yu. P. (2015). Competitiveness and export potential of cherry fruits grown under the conditions of Ukrainian forest-steppe [Competity and export potential of the sweet cherry fruits grown in the Ukraine's Lisosteppe]. Scientific reports of the National University of Life and Environmental Science of Ukraine, 52(3). http//www.nd.nubip. edu.ua/2015_3/11.pdf. [In Ukrainian].

20. Kishchak, O. A. (2017). Osnovy promyslovoi kultury chereshni v Lisostepu Ukrainy [Grounds of the sweet cherry industrial cultivation in the Ukraine's Lisosteppe]. Kyiv: Agrarian science. [In Ukrainian].

21. Karpenchuk, G. K., \& Melnyk, A. V. (1987). Uchioty, nabludieniia, analizy, obrabotka dannych v opytach s plodovymi i iagodnymi rastieniami: mietodichieskiie riekomiesndacii [Calculations, observations, analyses and data procession in the experiments on the fruit and small fruit plants: methodical recommendations]. Uman: Uman Agricultural Institute. [In Russian].

22. Syedov, E. N., \& Ogoltsova, T. P. (eds.) (1999). Programma i mietodika sortoizuchieniia plodovych, iagodnych i oriechoplodnych kultur [Programm and methods of the strain investigation of fruit, small fruit and nuciferous crops]. Oryol: VribB FC. [In Russian].

23. Bujdoso, G., Hrotkó, K., Quero-Garcia, J., Lezzoni, A., Puławska, J., \& Lang, G. (2017). Cherry production. CAB. International. Cherries: Botany, production and uses, 1-13. doi: $10.1079 / 9781780648378.0001$.

24. Long, L. E., Brewer, L. J., \& Kaiser, C. (2014). Cherry rootstock for the modern orchard. Proceedings of the $57^{\text {th }}$ Annual IFTA Symposium in Kelowna, British Columbia, Canada, Compact Fruit Tree, 24-28.

25. Blažková, J., \& Hlušičková, I. (2017). Results of an orchard trial with new clonal sweet cherry rootstocks established at Holovousy and evaluated in the stage of full cropping. Horticultural Science Hort, 34(2), 54-64.

26. Bujdoso, G. (2004). Evaluation of three sweet cherry cultivars and one sour cherry hybrid on dwarfing rootstocks. Acta Horticulturae, 658, 119-123. doi: 10.17660/ActaHortic.2004.658.15.

27. Milic, B., Kalajdzic, J., Keserovic, Z. et al. (2019). Early performance of four sweet cherry Cultivars grafted on Gizela 5 and Colt rootstocks in a high density growing system. Acta scientiarum polonorum hortorum cultus, 18, 99-108. doi: 10.24326/asphc.2019.1.10. 